Article

\title{
Effect of Different Green Extraction Methods and Solvents on Bioactive Components of Chamomile (Matricaria chamomilla L.) Flowers
}

\author{
Jana Šic Žlabur ${ }^{1}{ }^{1}$, Ivanka Žutić ${ }^{1}$, Sanja Radman ${ }^{1}{ }^{1}$, Maja Pleša ${ }^{1}$, Mladen Brnčić ${ }^{2}$,

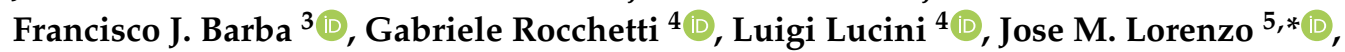 \\ Rubén Domínguez ${ }^{5}$ (D), Suzana Rimac Brnčić ${ }^{2}$, Ante Galić ${ }^{1}$ (D) and Sandra Voća ${ }^{1}$ (D) \\ 1 Faculty of Agriculture, University of Zagreb, Svetošimunska Cesta 25, 10000 Zagreb, Croatia; \\ jszlabur@agr.hr (J.Š.Ž.); izutic@agr.hr (I.Ž.); sradman@agr.hr (S.R.); maja00plesa@gmail.com (M.P.); \\ agalic@agr.hr (A.G.); svoca@agr.hr (S.V.) \\ 2 Faculty of Food Technology and Biotechnology, University of Zagreb, Pierottijeva ulica 6, \\ 10000 Zagreb, Croatia; mbrncic@pbf.hr (M.B.); srimacbrncic@pbf.hr (S.R.B.) \\ 3 Nutrition and Food Science Area, Preventive Medicine and Public Health, Food Science, Toxicology and \\ Forensic Medicine Department, Faculty of Pharmacy, Universitat de València, Avda. Vicent Andrés Estellés, \\ s/n 46100 Burjassot, València, Spain; francisco.barba@uv.es \\ 4 Department for Sustainable Food Process, Università Cattolica del Sacro Cuore, Via Emilia Parmense 84, \\ 29122 Piacenza, Italy; gabriele.rocchetti@unicatt.it (G.R.); luigi.lucini@unicatt.it (L.L.) \\ 5 Centro Tecnológico de la Carne de Galicia, Adva. Galicia n 4, Parque Tecnológico de Galicia, \\ 32900 San Cibrao das Viñas, Ourense, Spain; rubendominguez@ceteca.net \\ * Correspondence: jmlorenzo@ceteca.net; Tel.: +34-988-548-277
}

Academic Editor: Lillian Barros

Received: 27 January 2020; Accepted: 10 February 2020; Published: 13 February 2020

\begin{abstract}
Chamomile (Matricaria chamomilla L.) dried flowers contain a group of interesting biologically active compounds such as sesquiterpenes, flavonoids, coumarins, vitamins, phenolic acids and glucosides. Therefore, the aim of the present study was to characterize the composition in bioactive compounds (specialized metabolites) present in water and ethanol extracts of chamomile flowers, together with monitoring the impact of different extraction techniques (conventional vs. ultrasound-assisted extraction (UAE)) on the parameters under investigation. UAE treatment significantly decreased the extraction time of bioactive compounds from herbal material. Polyphenolic compounds content and antioxidant capacity were significantly higher in UAE extracts. Moreover, solvent type had a significant impact on the specialized metabolites content, while the highest vitamin $\mathrm{C}$ and polyphenols content were recorded in $50 \%$ ethanol $(v / v)$ extracts. Optimization of basic extraction factors: solvent type, temperature and technique is crucial for obtaining the extracts with the highest content of specialized metabolites and antioxidant capacity.
\end{abstract}

Keywords: German chamomile; ultrasound; conventional extraction; bioactive compounds; antioxidant capacity

\section{Introduction}

Chamomile (Matricaria chamomilla, synonym Matricaria recutita (L.) Rauschert) is a popular aromatic, medicinal herb mostly used in therapeutic purposes. Dried flowers and essential oil are the most widely used products mainly because it has multiple medicinal properties from antiinflammatory, analgesic, antimicrobial and antispasmic to sedative [1]. The most common variety in use is German chamomile (Matricaria chamomilla), while from the Asteraceae family well known variety is also Roman chamomile (Chamaemelum nobile). 
Mentioned varieties strongly differs both in morphological and chemical composition primarily in the content of biologically active compounds including essential oils and several polyphenols [2,3]. Aqueous and alcoholic (methanol and ethanol) extracts of chamomile are prepared from dried flowers and used as foods, like herbal teas or like tinctures mostly in pharmaceutical and medicinal purposes. Even, currently the most popular chamomile product in use is a form of herbal tea consumed over million cups per day [3,4]. Moreover, more recent studies highlight a significant anticancer properties of chamomile extracts including anti-proliferative and apoptotic activity in various human cancer cells with minimal effect on normal cells [5-7].

In the production of extracts from natural sources various isolation techniques are combined while more and more attention is gained to the techniques focused to the principles of "green chemistry", which among other things assumes using environmentally safe and nontoxic solvents [8-11]. For the extraction of various phytochemicals, specifically polyphenolic compounds the efficient solvents are usually ethanol, methanol, glycerol and their water solutions [12-15]. However, more attention has been gained to the use of solvents Generally Recognized As Safe (GRAS), such as water [16].

As above mentioned according to the principles of "green chemistry", innovative extraction techniques are more developed and general increasingly used for isolation of various phytonutrients [17]. For instance, ultrasound-assisted extraction (UAE) shows a number of advantages in the extraction of different chemical compounds from plant materials, from the increased yield of the compound to significant energy savings and time reduction $[14,18,19]$.

Therefore, the aim of the present study was to characterize the composition in bioactive compounds present in water and ethanol extracts of chamomile flowers, together with monitoring the impact of different extraction techniques (conventional vs UAE) on the parameters under investigation.

\section{Results and Discussion}

\subsection{Organic Acids and Physicochemical Properties of Chamomile Extracts}

Aromatic herbs are not characterized by a high content of organic acids, so low levels of total acid (TA) content determined in chamomile extracts regardless of the used solvent, extraction method or time is expected (Figure 1A). In aqueous extracts treated conventionally (C1-C12) the TA content was $0.67 \%$ while in ethanolic extracts (C13-C24) TA content was significantly lower (0.03\%). In aqueous extracts, it was observed a significant positive impact of temperature and time for TA content since a higher temperature of extraction $\left(60^{\circ} \mathrm{C}\right)$ and longer extraction time $(35 \mathrm{~min})$ promoted an increased TA content. The highest TA content $(0.93 \%)$ in aqueous extracts treated conventionally was determined in $\mathrm{C} 12$ treatment. On the other hand, in ethanolic extracts, alcohol concentration and time did not significantly influence TA content. 

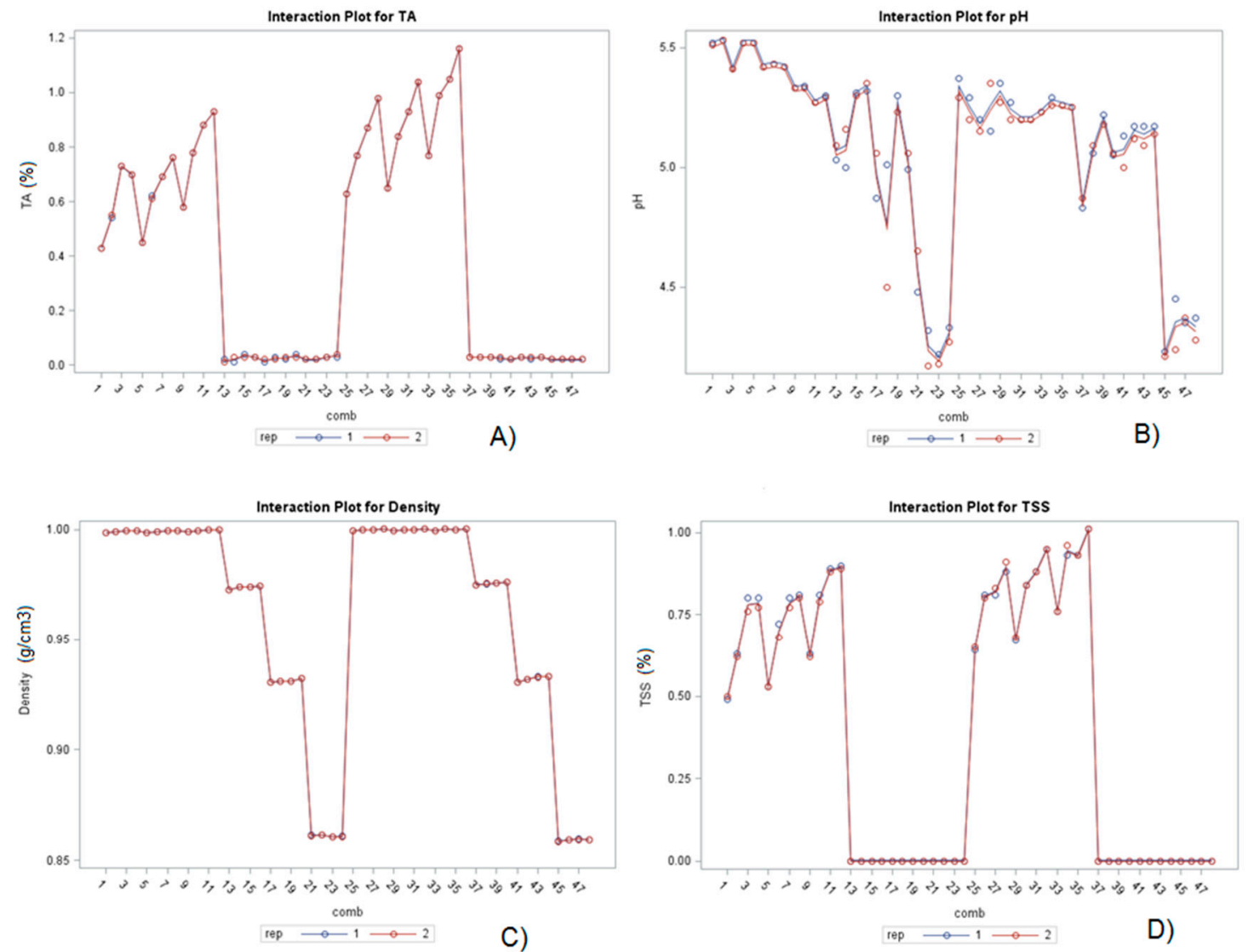

Figure 1. Interaction plots of physicochemical properties (A) total acids; (B) $\mathrm{pH}$; (C) density and (D) total soluble solids of chamomile (cv. 'Pitoma') water (1-12 and 25-36) and ethanol extracts (13-24 and 37.48) in conventional (C1-C24) and UAE (U25-48) treatments.

UAE treatment positively influenced $(p<0.001)$ on the TA content in aqueous extracts (U25-U36), in which was determined on average $32 \%$ higher TA content compared to the water extracts treated conventionally (Figure 1A). Moreover, longer extraction periods and higher temperature positively influenced on the TA content like in conventional extraction with the highest TA content (1.16\%; sample U36).

Regarding ethanolic extracts, UAE did not significantly influence TA content since the average TA content for treatments U37-U48 was the same as for samples C13-C24. According to the determined low TA values for both water and ethanol extracts, relatively high $\mathrm{pH}$ values were observed in conventional and UAE extractions. The average $\mathrm{pH}$ value determined for aqueous extracts treated conventionally was 5.41 (C1-C12), for ethanol extracts (C13-C24) 4.84, while for aqueous extracts treated by UAE (U25-U36) 5.24 and for ethanolic extracts (U37-U48) 4.82.

As expected, density values significantly differed according to the temperature and ethanol concentration used. For aqueous extracts, the highest density both in conventional $\left(0.9999 \mathrm{~g} \mathrm{~cm}^{-3}\right)$ and UAE $\left(1.0003 \mathrm{~g} \mathrm{~cm}^{-3}\right)$ was determined in the sample treated using a temperature of $60^{\circ} \mathrm{C}$. Samples with higher ethanol $\left(80 \%\right.$, U45-U48) had the lowest density (on average $0.8592 \mathrm{~g} \mathrm{~cm}^{-3}$ ) with no significant impact of the extraction method.

Likewise, total soluble solids (TSS) were only determined in aqueous extracts. Temperature increase $\left(60^{\circ} \mathrm{C}\right)$ positively influenced on the TSS content in the aqueous extracts, observing the highest values $(0.90 \%$ and $1.01 \%$, respectively) in the samples C12 and U36, respectively. Regardless of the water temperature and time period, UAE significantly influenced on the increase of the TSS content (about $16 \%$ ) compared to the conventional extraction. 
Different research studies suggested opposite results regarding the impact of UAE on the physicochemical parameters of liquid samples. For example, Aadil et al. [20] and Zou et al. [21,22] did not determine any changes of TA, TSS and pH values in UAE-treated samples, while other authors obtained a positive impact of UAE on the mentioned parameters [23]. The main reason for such significant variability in results found in the available literature is strongly correlated with the main condition parameters affecting the cavitation phenomenon during UAE. Namely, lower applied ultrasound frequencies results in the formation of bubbles with critical diameter, which easily collapse during compression cycles inducing the release of large amounts of heat and shockwaves, creating localized temperatures increase around $5000 \mathrm{~K}$ and pressure jets over $100 \mathrm{MPa}$, called transient cavitation [24,25]. Mild temperature increase in UAE systems as a direct effect of transient cavitation may affect some physical properties of the liquid such as density, TA, TSS and $\mathrm{pH}$.

Interaction analysis of the main varied factors: extraction method (EM), solvent type (S) and time $(t)$ in chamomile extracts is shown in Table 1. According to the obtained results, the interaction between factors $E M \times S$ significantly influenced on the all observed physicochemical parameters, while interaction between $\mathrm{S} \times \mathrm{t}$ did not influence on the $\mathrm{pH}$ and density. Interaction between EM $\times \mathrm{t}$ did not significantly influence to any of the analyzed parameters. Moreover, the interaction between all the varied factors in the present study research $(\mathrm{EM} \times \mathrm{S} \times \mathrm{t})$ significantly affected all the analyzed parameters.

Table 1. The significance of the factor interactions in chamomile extracts for analyzed physicochemical properties.

\begin{tabular}{ccccc}
\hline \multicolumn{5}{c}{ Significance of the Factor Interactions } \\
\hline Factor Interactions & $\begin{array}{c}\text { TA } \\
\mathbf{P r} \leq \mathbf{F}\end{array}$ & $\begin{array}{c}\mathbf{p H} \\
\mathbf{P r} \leq \mathbf{F}\end{array}$ & $\begin{array}{c}\text { Density } \\
\mathbf{P r} \leq \mathbf{F}\end{array}$ & $\begin{array}{c}\text { TSS } \\
\mathbf{P r} \leq \mathbf{F}\end{array}$ \\
\hline $\mathrm{EM} \times \mathrm{S}$ & 0.0001 & 0.0001 & 0.0001 & 0.0225 \\
$\mathrm{~S} \times \mathrm{t}$ & 0.0005 & 0.0788 & 0.8988 & 0.0001 \\
$\mathrm{EM} \times \mathrm{t}$ & 0.9987 & 0.9290 & 1.0000 & 0.9974 \\
$\mathrm{EM} \times \mathrm{S} \times \mathrm{t}$ & 0.0001 & 0.0001 & 0.0001 & 0.0001 \\
\hline
\end{tabular}

$\mathrm{EM} \times \mathrm{S}$ - extraction method and type of solvent; $\mathrm{S} \times \mathrm{t}$-solvent and time; $\mathrm{EM} \times \mathrm{t}-$ extraction method and time; $\mathrm{EM} \times \mathrm{S} \times \mathrm{t}$ - extraction method, solvent and time.

\subsection{Bioactive Content and Antioxidant Capacity of the Different Chamomile Extracts}

Regardless of the solvent type and time, significantly lower vitamin C content was determined in the UAE-treated samples (U25-U48; Figure 2A). On average, after conventional extraction, the vitamin $\mathrm{C}$ content of aqueous extracts was $25 \%$ higher compared to the UAE-treated extracts. Moreover, higher concentrations of ethanol (80\%) significantly contributed to an increase of vitamin C content in chamomile extracts compared to the other solvents $\left(\mathrm{H}_{2} \mathrm{O} 21.4,40\right.$ and $60{ }^{\circ} \mathrm{C}$ and EtOH of $20 \%$ and $50 \%$ $v / v)$. The highest vitamin $C$ content $\left(15.98 \mathrm{mg} 100 \mathrm{~g}^{-1}\right)$ was determined for the sample C24, while the lowest values $\left(6.18 \mathrm{mg}, 100 \mathrm{~g}^{-1}\right)$ were found for the sample U27. The phenomenon of transient cavitation initiates chemical reactivity through thermolysis, supercritical water oxidation and free radical oxidation [24]. Impact of thermolysis but also the formation of hydrogen ions $\left(\mathrm{H}^{+}\right)$, free radicals $\left(\mathrm{O}^{-}, \mathrm{OH}^{-}\right.$and $\left.\mathrm{HO}_{2}{ }^{-}\right)$and hydrogen peroxide $\left(\mathrm{H}_{2} \mathrm{O}_{2}\right)$ might be a possible explanation for the slight vitamin $\mathrm{C}$ degradation noticed in chamomile extracts in the present research. Most of literature data cited a positive effect of UAE on the vitamin $C$ content but also some of them emphasized about the possibility of vitamin $C$ degradation during sonolysis [26,27]. 


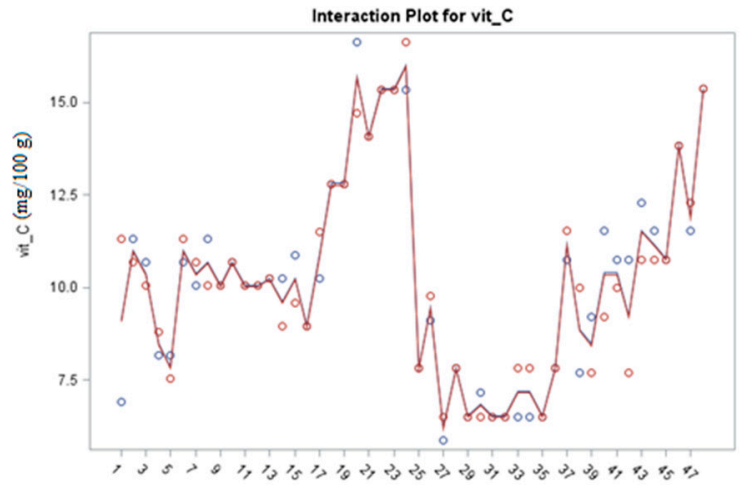

A) rep $\longrightarrow-1 \longrightarrow 2$

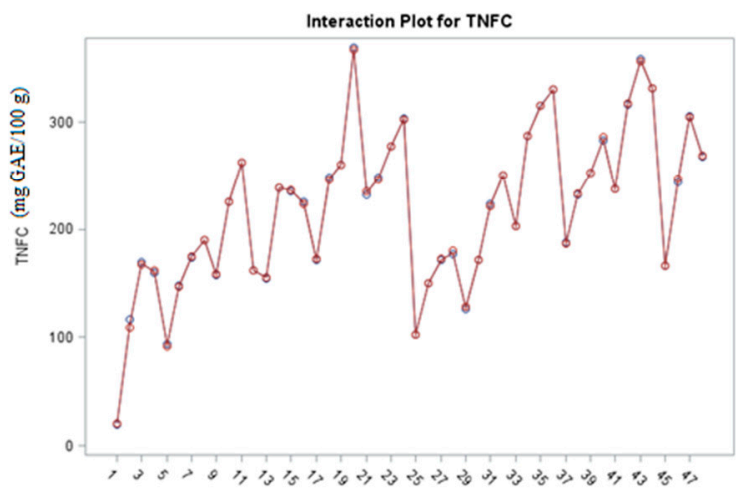

C) rep $\longrightarrow 1-2$

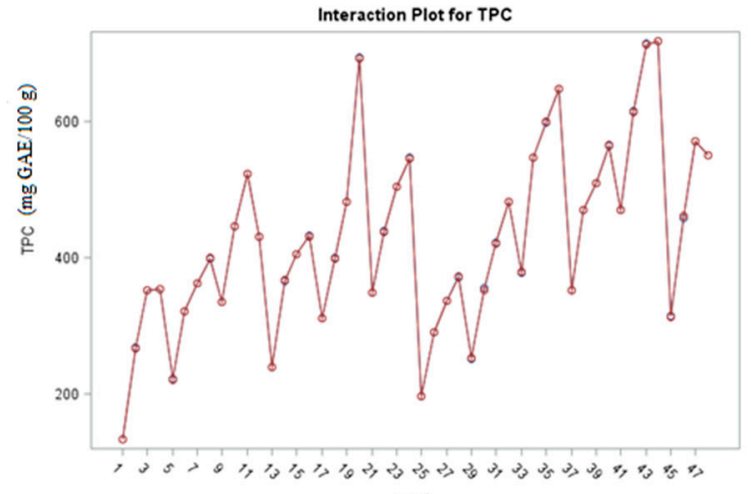

B) rep $\because-1 \multimap-2$

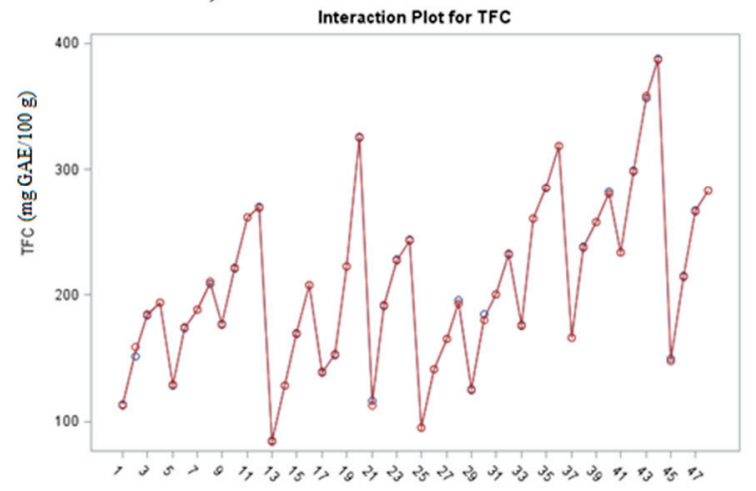

D) rep $\longrightarrow-1 \multimap 2$

Figure 2. Interaction plot of vitamin C (A), total phenol (TPC; B), total non-flavonoid content (TNFC; C) and total flavonoid (TFC; D) content in chamomile (cv. 'Pitoma') water (1-12 and 25-36) and ethanol extracts (13-24 and 37.48) in conventional (C1-C24) and UAE (U25-48) treatments.

Besides the mentioned changes based on the chemical reactions occurring as a direct result of cavitation phenomena, sonication treatment (transient cavitation) also can promote a cell wall disruption, thus facilitating the release of various phenolic compounds. Chamomile extracts treated by UAE had significantly higher total phenol (TPC) content, even $20 \%$, compared to the extracts conventionally treated (Figure $2 \mathrm{~B}$ ) regardless of the solvent type and time.

Both, after conventional and UAE extractions, TPC significantly differed between aqueous extracts prepared at different solvent temperatures with significantly higher TPC values recorded in extracts treated with higher temperature, $60{ }^{\circ} \mathrm{C}$ (C9-C12 and U33-U36) compared to the 21.4 (C1-C4 and $\mathrm{U} 25-\mathrm{U} 28)$ and $40{ }^{\circ} \mathrm{C}$ (C5-C8 and U29-U32). In conventional treatments even $22 \%$ higher TPC and $8 \%$ in samples treated at $60{ }^{\circ} \mathrm{C}$ compared to the 21.4 and $40{ }^{\circ} \mathrm{C}$, while in UAE even $74 \%$ and $35 \%$ higher $\mathrm{TPC}$ at $60^{\circ} \mathrm{C}$ compared to the two other combined temperatures.

On the other hand, ethanol concentration significantly influenced TPC yield, independently of the extraction method used. In general, the highest TPC was determined in samples with 50\% $\mathrm{EtOH}(v / v)$ compared to the samples with $20 \%$ or $80 \%$ EtOH. In UAE extracts with $50 \%$ EtOH (U41-U44), it was found a TPC even 33\% higher compared to the extracts prepared with $20 \%$ and $80 \% \mathrm{EtOH}$. A similar trend was also observed for TPC after conventional extraction considering the EtOH concentration.

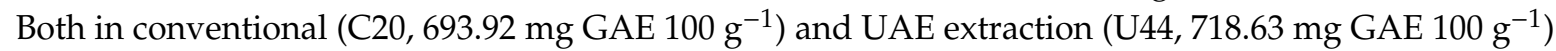
the highest TPC content was obtained in the extracts with $50 \% \mathrm{EtOH}$, and subsequent extraction for $35 \mathrm{~min}$. The same trend observed for TPC was also found for total non-flavonoid (TNFC) and total flavonoid (TFC) compounds when the conventional and UAE extractions were compared.

In UAE chamomile extracts (U25-U48) was found with $18 \%$ higher TNFC (Figure 2C) and $23 \%$ TFC (Figure 2D) regardless of the solvent type and time compared to the extracts conventionally 
treated (C1-C24). A positive impact of higher solvent temperature $\left(60^{\circ} \mathrm{C}\right)$ in water extracts was also observed for the content of TNFC and TFC, both in conventional and UAE treatments. TNFC in water extracts conventionally treated with $60{ }^{\circ} \mathrm{C} \mathrm{H}_{2} \mathrm{O}(\mathrm{C} 9-\mathrm{C} 12)$ was $33 \%$ higher compared to the extracts conventionally treated with $40{ }^{\circ} \mathrm{C} \mathrm{H}_{2} \mathrm{O}(\mathrm{C} 5-\mathrm{C} 8)$ and even $74 \%$ higher compared to the extracts conventionally treated with $\mathrm{H}_{2} \mathrm{O}$ at room temperature $(\mathrm{C} 1-\mathrm{C} 4)$.

In UAE extraction even higher positive temperature impact for TNFC was determined since even $47 \%$ higher values were determined in water extracts prepared with $60^{\circ} \mathrm{C} \mathrm{H}_{2} \mathrm{O}$ (U33-U36) compared to those prepared with $40^{\circ} \mathrm{C}_{2} \mathrm{O}$ (U29-U32) and $88 \%$ higher compared with extracts prepared with $\mathrm{H}_{2} \mathrm{O}$ at room temperature (U25-U28). The ethanol concentration of 50\% (v/v) significantly contributed to the extraction of TNFC, both in conventional and UAE treatments since in ethanolic extracts prepared with 50\% EtOH was determined the highest TNFC (C17-C20 and U41-U44). Higher TFC values were determined in water extracts prepared with $60{ }^{\circ} \mathrm{C} \mathrm{H}_{2} \mathrm{O}(\mathrm{C} 9-\mathrm{C} 12)$, about $33 \%$ higher compared to the extracts prepared with $40^{\circ} \mathrm{C} \mathrm{H}_{2} \mathrm{O}(\mathrm{C} 5-\mathrm{C} 8)$ and $44 \%$ higher compared to the extracts $\mathrm{C} 1-\mathrm{C} 4\left(\mathrm{H}_{2} \mathrm{O}\right.$ room temperature $)$ in conventional treatment, while $41 \%$ higher in extracts U33-U36 $\left(60{ }^{\circ} \mathrm{C} \mathrm{H}_{2} \mathrm{O}\right)$ compared to the those prepared with $40{ }^{\circ} \mathrm{C} \mathrm{H}_{2} \mathrm{O}$ (U29-U32) and 75\% compared to extracts prepared with $\mathrm{H}_{2} \mathrm{O}$ room temperature (U25-U28). Moreover, both conventional and UAE treatments had the highest TFC in the samples treated with 50\% EtOH (Figure 2D).

Different previous research studies confirmed the positive impact of sonication treatment on the content of polyphenolic compounds: total phenols, flavonoids, phenolic acids, flavones, flavonols, etc. $[21,23,28-31]$. Namely, besides cell wall destruction as a direct mechanical result of transient cavitation, different reactions at the chemical level can occur during sonication [32,33]. During sonolysis, as before mentioned, free radicals: $\mathrm{O}^{-}, \mathrm{OH}^{-}$and $\mathrm{HO}_{2}{ }^{-}$are formed. $\mathrm{OH}^{-}$radicals improve the functionality of polyphenolic compounds, thus increasing the hydroxylation degree and consequently as the hydroxylation degree is higher, functionality of polyphenols could be improved [34].

The analysis of the significance of the factor interactions in chamomile extracts for bioactive compounds and antioxidant activity (Figure 3) shows the highest significance $(p \leq 0.0001)$ in the interaction of all three varied variables: extraction method, solvent type and time, $E M \times S \times t$ for all mentioned parameters (Table 2). Different combinations of factors, besides $\mathrm{EM} \times \mathrm{S} \times \mathrm{t}$ did not show any significance for specialized metabolites except for the extraction method and solvent type $(E M \times S)$ for TFC.

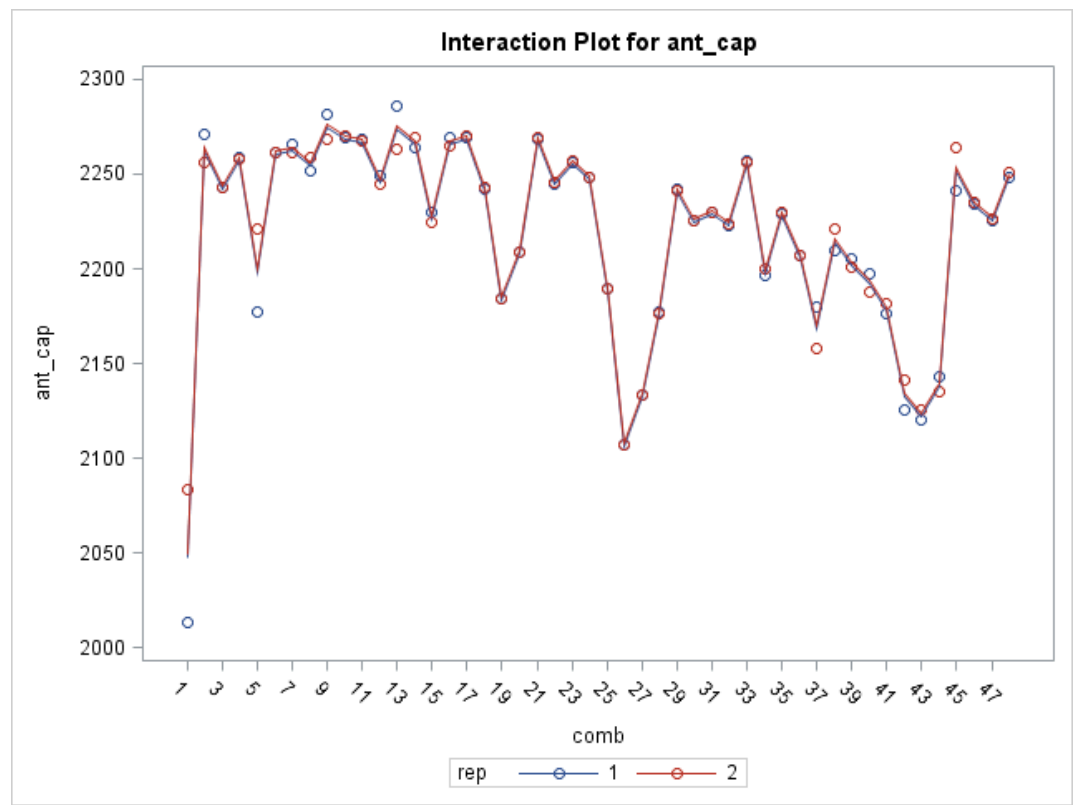

Figure 3. Interaction plot of antioxidant capacity (ant_cap) in chamomile (cv. 'Pitoma') water (1-12 and 25-36) and ethanol extracts (13-24 and 37.48) in conventional (C1-C24) and UAE (U25-48) treatments. 
Table 2. The significance of the factor interactions in chamomile extracts for specialized metabolites and antioxidant activity.

\begin{tabular}{cccccc}
\hline \multicolumn{7}{c}{ Significance of the Factor Interactions } \\
\hline \multirow{2}{*}{ Factor Interactions } & VIT_C & TPC & TNFC & TFC & Ant_act \\
& Pr $\leq \mathbf{F}$ & $\mathbf{P r} \leq \mathbf{F}$ & $\mathbf{P r} \leq \mathbf{F}$ & $\mathbf{P r} \leq \mathbf{F}$ & $\operatorname{Pr} \leq \mathbf{F}$ \\
\hline $\mathrm{EM} \times \mathrm{S}$ & 0.0088 & 0.2264 & 0.1166 & 0.0082 & 0.0537 \\
$\mathrm{~S} \times \mathrm{t}$ & 0.3480 & 0.7632 & 0.6586 & 0.7108 & 0.1775 \\
$\mathrm{EM} \times \mathrm{t}$ & 0.6927 & 0.9780 & 0.9891 & 0.8958 & 0.1118 \\
$\mathrm{EM} \times \mathrm{S} \times \mathrm{t}$ & 0.0001 & 0.0001 & 0.0001 & 0.0001 & 0.0001 \\
\hline
\end{tabular}

$\mathrm{EM} \times \mathrm{S}$ - extraction method and type of solvent; $\mathrm{S} \times \mathrm{t}-$ solvent and time; $\mathrm{EM} \times \mathrm{t}-$ extraction method and time; $\mathrm{EM} \times \mathrm{S} \times \mathrm{t}-$ extraction method, solvent and time.

\subsection{Multivariate Statistics to Discriminate the Different Extraction Conditions}

The orthogonal projections to latent structures discriminant analysis (OPLS-DA) supervised approach was used in order to evaluate the impact of the different extraction conditions on the two chamomile cultivars (i.e., 'Pitoma' and 'Bode Gold'). The OPLS-DA analysis allows us to identify which variables are driving the separation between two groups of observation. In particular, when considering the OPLS-DA score scatter plot, the horizontal direction of this plot will capture the variation between the groups, while the vertical dimension and any higher component of the so-called orthogonal type will capture variation within the groups. In our experimental conditions, the dataset based on $\mathrm{pH}$, density, TSS, TA, alcohol volume content, vitamin C, TPC, TFC, TFNC and antioxidant capacity for both cultivars was used for building OPLS-DA models.

According to our experimental conditions, four OPLS-DA models were built. For both cultivars, the extraction solvent (i.e., hydroalcoholic vs water) was used as a class membership criterion, in order to identify the main differences during the four time periods considered (i.e., 5, 15, 25 and $35 \mathrm{~min}$ ). The first OPLS-DA model is reported in Figure 4, regarding the use of conventional extraction method for the Pitoma cultivar. As can be observed from the Figure 4A, a clear separation between water and hydroalcoholic extracts was observed, thus confirming the different extraction efficiency in terms of solvent used. Afterwards, by inspecting each replicate of the OPLS-DA score plot (Figure 4B), it was clear that the extraction time was very effective in determining the differences in the profiles observed. In particular, we found that the most distinct profiles for conventional extractions were obtained when long extraction times were used (i.e., 25 and $35 \mathrm{~min}$, respectively). Interestingly, the conventional extraction using ethanol $50 \%$ as solvent for $35 \mathrm{~min}$, produced chemical profiles similar to those obtained by using ethanol $80 \%$ for 25 and $35 \mathrm{~min}$. 
(A)

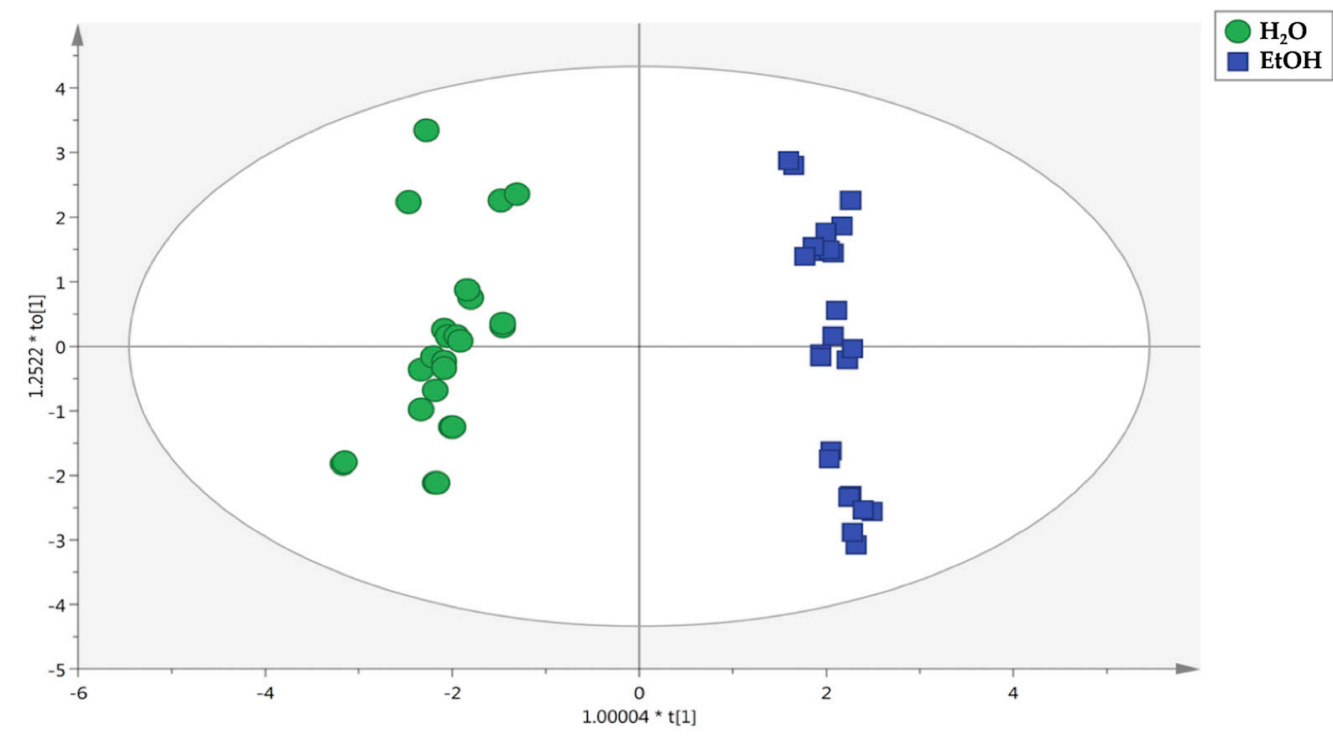

(B)

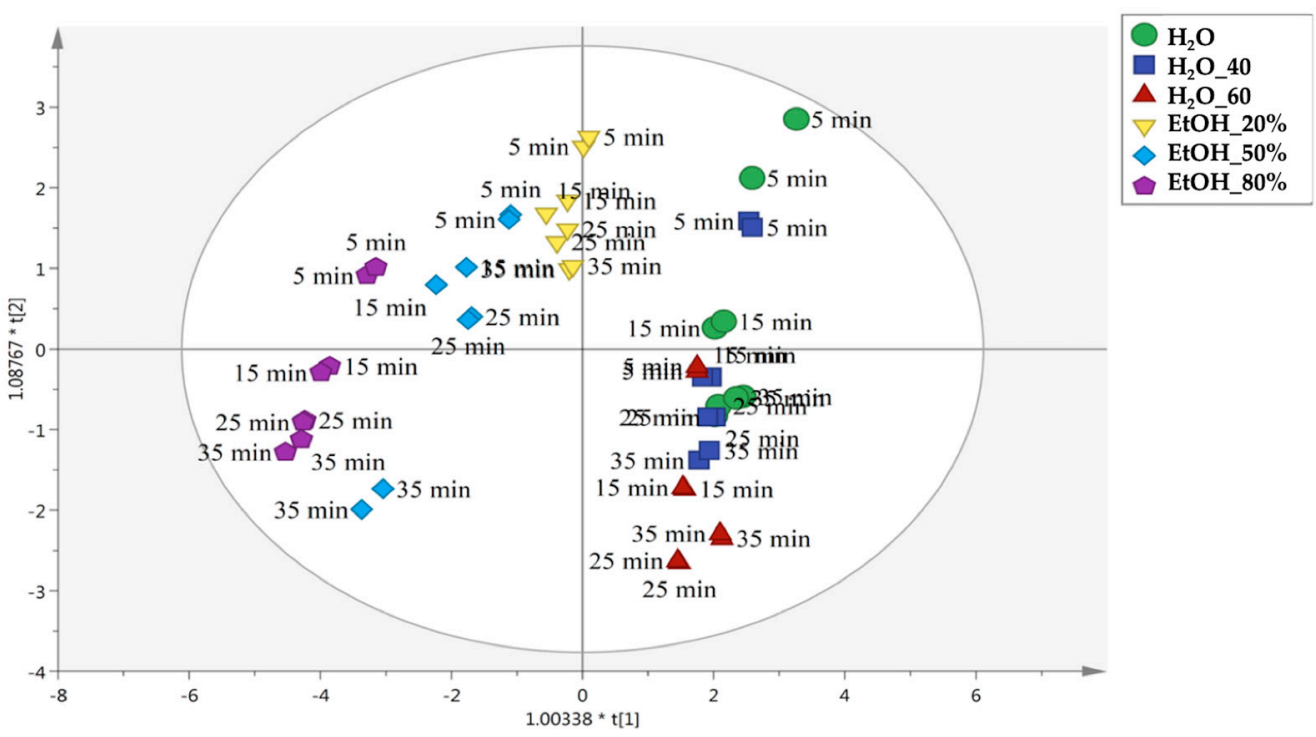

Figure 4. Orthogonal projections to latent structures discriminant analysis (OPLS-DA) to discriminate samples belonging to the Pitoma cultivar and extracted by the means conventional method. The score plots are built considering as class membership criteria both solvent type (A) and extraction time (B).

The second OPLS-DA model built considering the Pitoma cultivar samples extracted by UAE is reported in Figure 5. The same good separation between aqueous and alcoholic extracts was observed (Figure 5A). Interestingly, the OPLS-DA model on UAE treated samples allowed us to identify definitely different results when compared with conventional extracts. In fact, as shown in Figure 5B, we found that using ethanol $80 \%$ as extraction solvent for $5 \mathrm{~min}$ was able to produce the most differential profiles. Overall, the extraction time seemed to not play a crucial role in determining differences, when considering the water extracts. In fact, most of the differences for UAE water extracts were observed when using distilled water at $60^{\circ} \mathrm{C}$ for 25 and $35 \mathrm{~min}$. Therefore, the OPLS-DA models built for the Pitoma cultivar suggested that the combination of extraction solvent $\times$ extraction time should be carefully evaluated in order to promote differences in the chemical parameters investigated. 


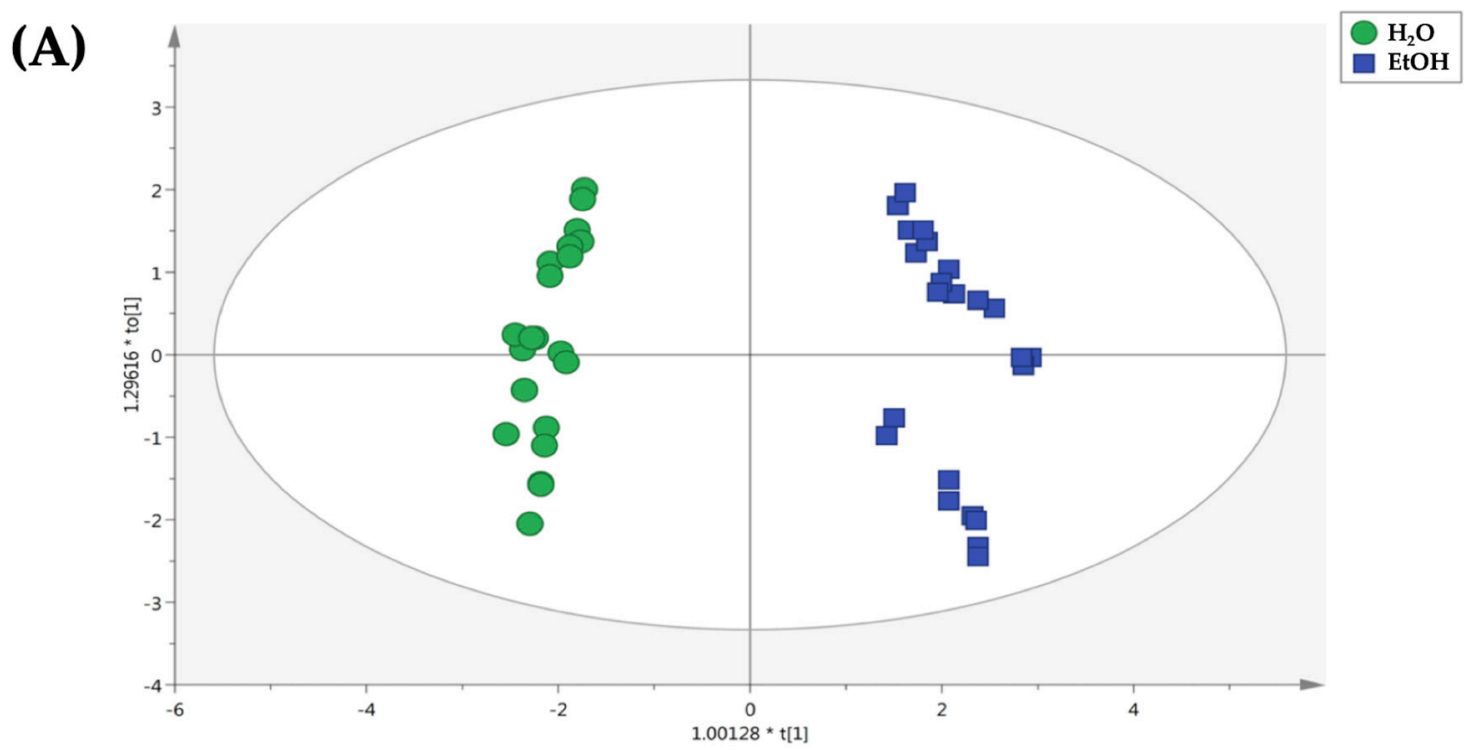

(B)

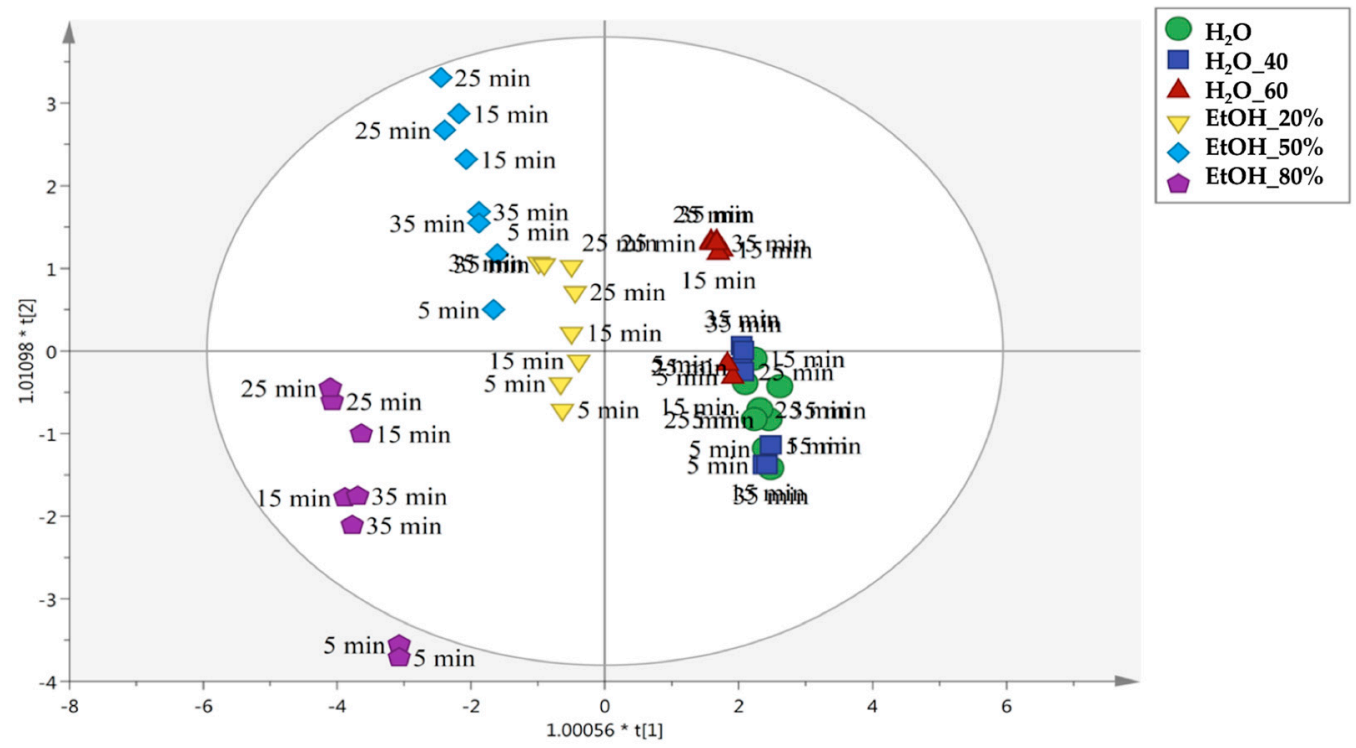

Figure 5. Orthogonal projections to latent structures discriminant analysis (OPLS-DA) to discriminate samples belonging to the Pitoma cultivar and extracted by means UAE. The score plots are built considering as class membership criteria both solvent type (A) and extraction time (B).

The third OPLS-DA model is reported in Figure 6, regarding the use of conventional extraction method for the Bode gold cultivar. As can be observed from the Figure 6A, similar results were obtained when comparing Pitoma and Bode gold score scatter plots. In this regard, a clear separation between water and hydroalcoholic extracts was obtained when considering the second latent vector of the predictive model, while the following OPLS-DA score plot (Figure 6B) built inspecting each replicate separately showed that ethanol $80 \%$ was the extraction solvent promoting the most different profile, independently from the extraction time considered. Overall, each different percentage (i.e., 20\%, 50\% and $80 \%$ of ethanol) allowed us to observe distinct signatures in the OPLS-DA score plot. Regarding water extracts, long extraction times combined with distilled water at $60^{\circ} \mathrm{C}$ allowed us to observe the most discriminant chemical profiles. 
(A)

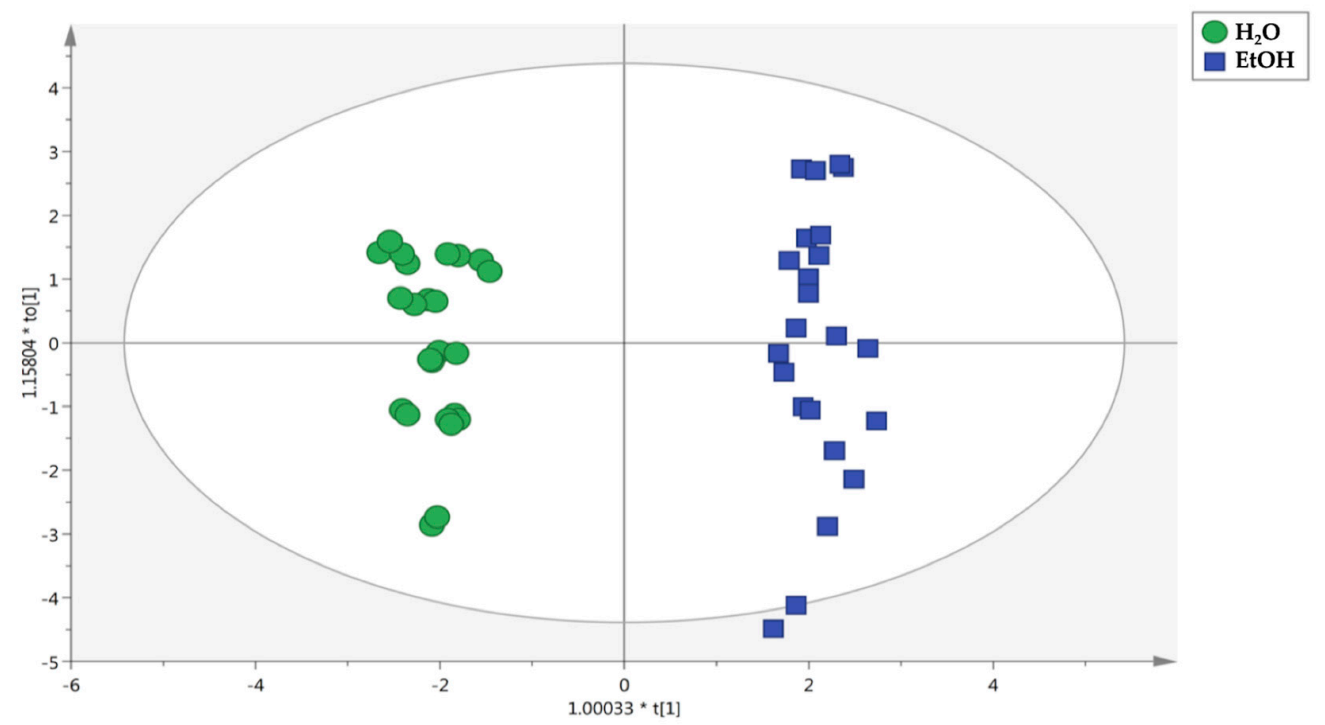

(B)

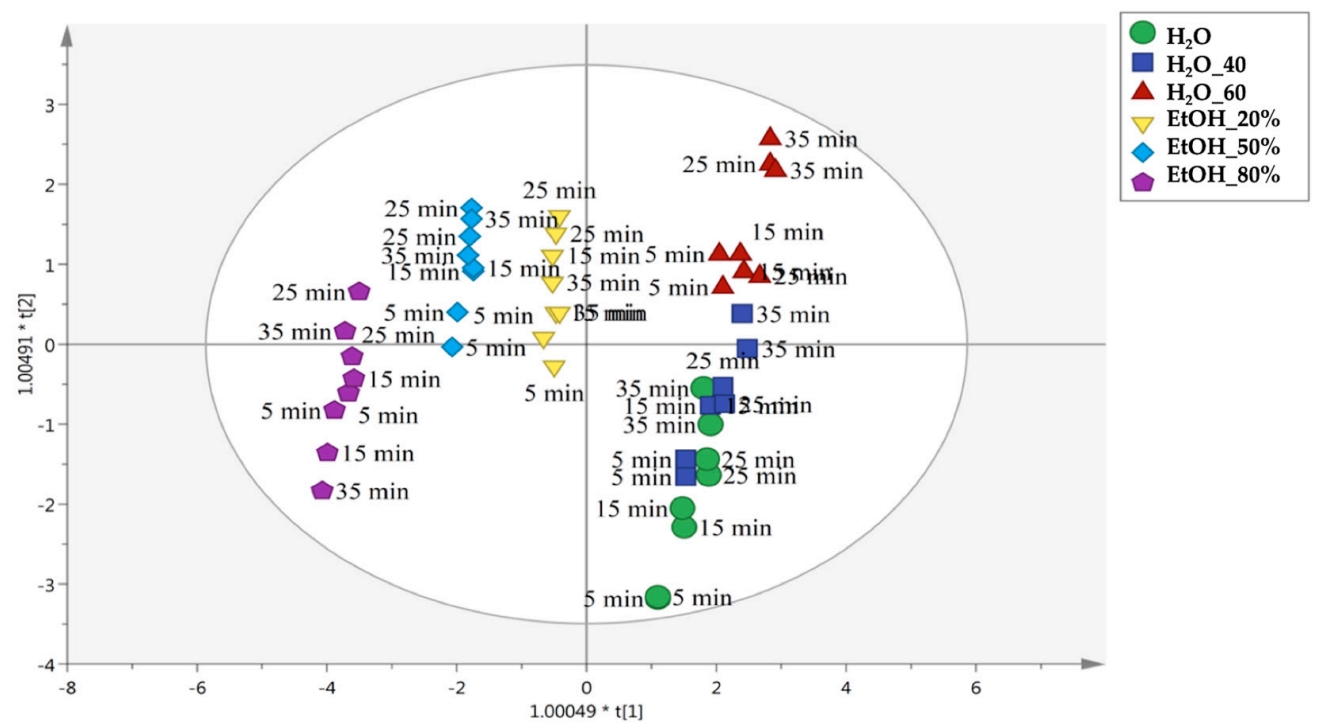

Figure 6. Orthogonal projections to latent structures discriminant analysis (OPLS-DA) to discriminate samples belonging to the Bode gold cultivar and extracted by the means conventional method. The score plots are built considering as class membership criteria both solvent type (A) and extraction time (B).

The fourth OPLS-DA model built considering Bode gold cultivar samples extracted by UAE is reported in Figure 7. It was found again a good separation degree between aqueous and hydroalcoholic extracts into the score scatter plot (Figure 7A). Interestingly, the OPLS-DA model on UAE treated samples showed definitely different trends when compared with conventional ones. In fact, as shown in Figure 7B, it was observed that using a different combination of ethanol as an extraction solvent (i.e., $20 \%, 50 \%$ and $80 \%$ ) produced the most differential profiles, independently from the extraction time. Therefore, the selection of the extraction solvent seemed to be more important when compared to the extraction time applied. Overall, water extracts at room temperature were found to cluster with water extracts at $40^{\circ} \mathrm{C}$. Interestingly, samples extracted in water at $60^{\circ} \mathrm{C}$ were grouped into the hyperspace together with those samples extracted with water at $40^{\circ} \mathrm{C}$ for $35 \mathrm{~min}$. 


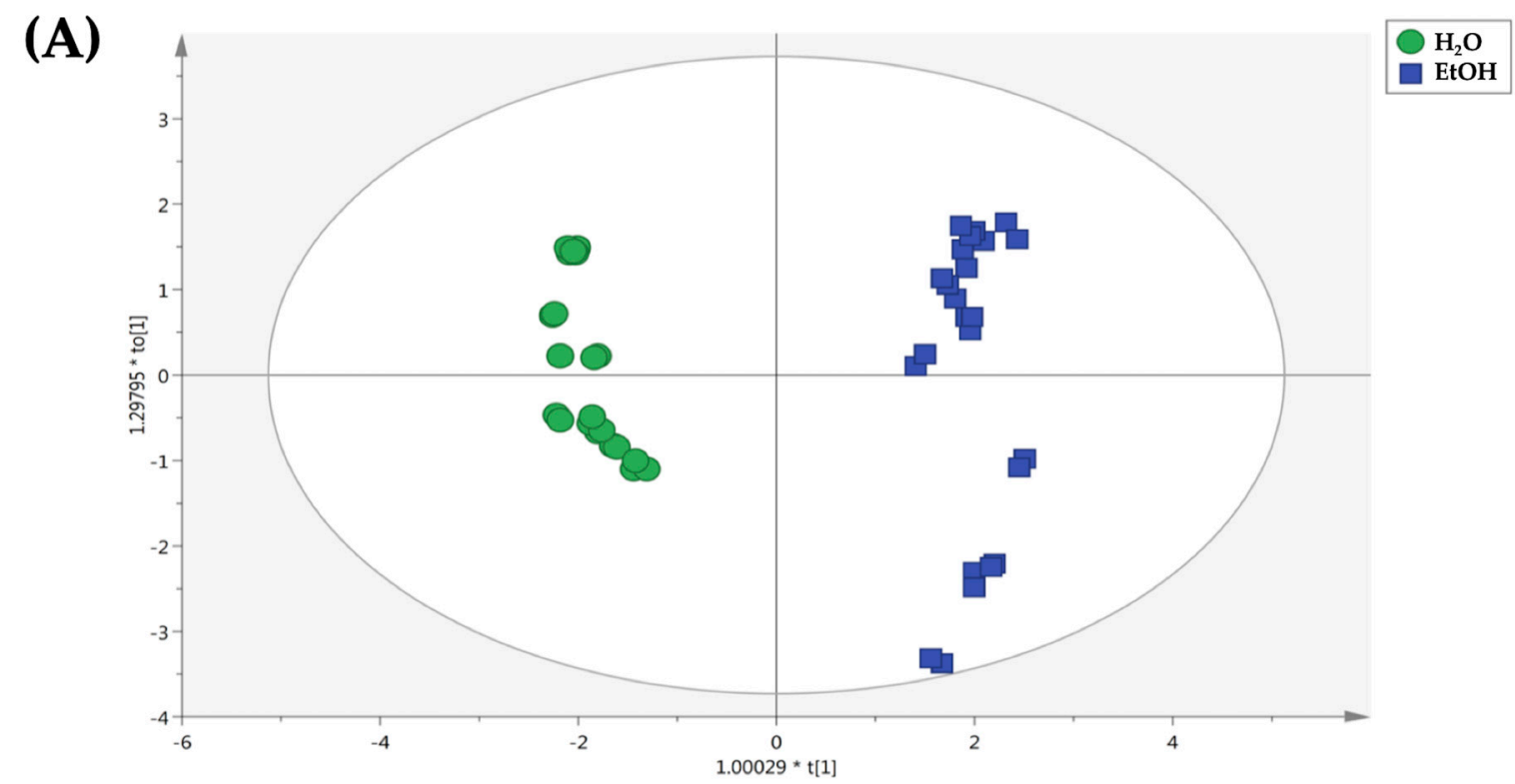

(B)

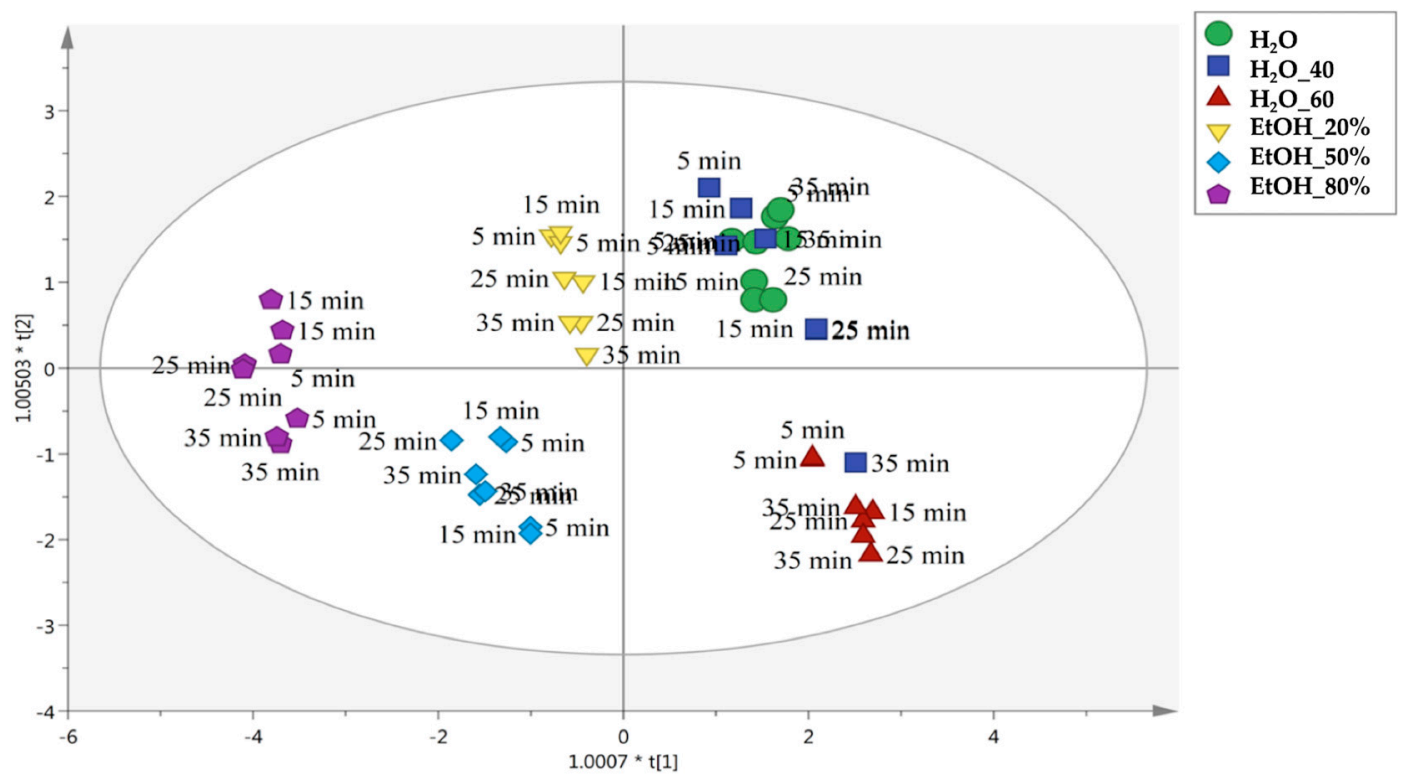

Figure 7. Orthogonal projections to latent structures discriminant analysis (OPLS-DA) to discriminate samples belonging to the Bode gold cultivar and extracted by means UAE. The score plots are built considering as class membership criteria both solvent type (A) and extraction time (B).

Finally, the variable selection method variables importance in projection (VIP) was used to identify those parameters allowing the score plot hyperspace distributions previously described (i.e., considering conventional and UAE extraction methods). The most discriminant parameters for both Pitoma and Bode gold cultivars are reported in Table 3; as can be observed, when considering the conventional extraction methods, the most discriminant and affected parameters were mainly: TSS, TA, volume content and density. However, using conventional extraction, vitamin $\mathrm{C}$ content was mainly affected in the Bode gold cultivar (VIP score $=1.07$ ) when compared with Pitoma (VIP score $<1$ ). Interestingly, the antioxidant capacity together with the parameters related to polyphenols (such as TPC and TFC) were not significantly affected by the two different extraction conditions (VIP scores $<1$ ). The VIP markers found for UAE OPLS-DA models are reported also in Table 4 and considering both cultivars. The common variables most affected by the extraction conditions for UAE were TSS, TA, 
volume content and density. All the other parameters presented VIP scores lower than 1, except for vitamin $C$ that was found to be very important in the OPLS-DA model built (VIP score $=1.08$ ) considering the Pitoma cultivar.

Table 3. VIP (variables importance in projection) selection method to identify those parameters discriminating chamomile extracts according to the different cultivars and extraction method.

\begin{tabular}{ccccc}
\hline & \multicolumn{2}{c}{ Conventional } & \multicolumn{2}{c}{ UAE } \\
\hline Variable OPLS-DA & Pitoma & Bode Gold & Pitoma & Bode Gold \\
\hline TSS & $1.27 \pm 0.11$ & $1.27 \pm 0.07$ & $1.26 \pm 0.25$ & $1.34 \pm 0.05$ \\
TA & $1.26 \pm 0.10$ & $1.26 \pm 0.05$ & $1.25 \pm 0.26$ & $1.32 \pm 0.05$ \\
Volume content & $1.14 \pm 0.09$ & $1.14 \pm 0.05$ & $1.12 \pm 0.22$ & $1.17 \pm 0.04$ \\
Density & $1.10 \pm 0.11$ & $1.10 \pm 0.06$ & $1.08 \pm 0.23$ & $1.14 \pm 0.06$ \\
pH & $1.02 \pm 0.11$ & $1.00 \pm 0.14$ & $0.92 \pm 0.22$ & $0.88 \pm 0.21$ \\
TFNC & $1.00 \pm 0.25$ & $0.70 \pm 0.31$ & $0.84 \pm 0.95$ & $0.74 \pm 0.19$ \\
Vitamin C & $0.93 \pm 0.10$ & $1.07 \pm 0.21$ & $1.08 \pm 0.26$ & $0.80 \pm 0.38$ \\
TPC & $0.84 \pm 0.28$ & $0.77 \pm 0.06$ & $0.85 \pm 0.95$ & $0.77 \pm 0.14$ \\
TFC & $0.71 \pm 0.23$ & $0.82 \pm 0.08$ & $0.85 \pm 0.92$ & $0.81 \pm 0.31$ \\
Antioxidant capacity & $0.34 \pm 0.98$ & $0.55 \pm 0.32$ & $0.43 \pm 1.00$ & $0.69 \pm 0.28$ \\
\hline
\end{tabular}

\section{Materials and Methods}

\subsection{Plant Material}

For research purposes German chamomile (Matricaria chamomilla) cv. 'Pitoma' was cultivated. Sowing was conducted in the period from 15 October to 1 November 2016 in an area of 34 ha in Kutina, Croatia. Before sowing, basic agricultural practices were carried out: ploughing, soil milling and rolling. Since the cultivation is carried out according to the principles of organic production, mineral fertilizers and plant protection products were not used. Chamomile flowers were picked up by machine pulled combine on 26 May 2017 and dried. Drying was carried out at a temperature of 42-45 ${ }^{\circ} \mathrm{C}$ for $24 \mathrm{~h}$. Dried flowers are packed in cardboard boxes and stored in a dry space until intended chemical analysis.

\subsection{Preparation of Extracts}

Preparation of chamomile extracts and all chemical analysis were conducted at the Department of Agricultural Technology, Storage and Transport at University of Zagreb Faculty of Agriculture. First, dried chamomile flowers were milled in laboratory mill (IKA MF-10, IKA®-Werke GmbH \& Co., Staufen, Germany). The dry matter content $(89.28 \%)$ of the chamomile flowers was determined using a conventional drying process at $105^{\circ} \mathrm{C}$ [35]. For the extraction purposes (both conventional and ultrasonic-assisted) $100 \mathrm{~mL}$ of the following solvents: (i) distilled water at different temperatures $\left(21.4,40\right.$ and $\left.60{ }^{\circ} \mathrm{C}\right)$ and (ii) ethanol $(\mathrm{EtOH})$ at different concentrations $(20 \%, 50 \%$ and $80 \%$, v/v), were added into $2.5 \mathrm{~g}$ of dried milled chamomile flowers. Such prepared samples were extracted for 5, 15, 25 and 35 min after each filtered through Whatman filter paper. For the ultrasound-assisted extraction (UAE) immediately after the addition of different solvents, samples were placed in the ultrasonic bath (RK $103 \mathrm{H}$, Bandelin, Germany) frequency of $35 \mathrm{kHz}$, maximal nominal output power of the device 140 $\mathrm{W}$ and sonicated in the same time intervals $(5,15,25$ and $35 \mathrm{~min})$. It should be noted that during UAE with distilled $\mathrm{H}_{2} \mathrm{O}$ at elevated temperatures $\left(40\right.$ and $\left.60{ }^{\circ} \mathrm{C}\right)$ the temperature in the ultrasonic bath was set up and maintained for 40 and $60{ }^{\circ} \mathrm{C}$. During sonication, the temperature in samples was measured with a laser thermometer (Raytek-MiniTemp FS, Raytek, Toronto, ON, Canada) in time intervals of $30 \mathrm{~s}$. The maximum recorded temperature during sonication of water extracts (was $64{ }^{\circ} \mathrm{C}$ for sample sonicated for $35 \mathrm{~min}$ and distilled $\mathrm{H}_{2} \mathrm{O}$ at $60{ }^{\circ} \mathrm{C}$, while for the ethanol extracts the maximum recorded temperature during sonication was $47^{\circ} \mathrm{C}$ for samples sonicated for $35 \mathrm{~min}$ and $\mathrm{EtOH}(80 \%, v / v)$ as the solvent. The experimental design set up for conventional and UAE is shown in Table 4 . 
Table 4. Experimental conditions for conventional (CONV) and ultrasound-assisted extraction (UAE).

\begin{tabular}{|c|c|c|c|c|c|}
\hline Solvent & Temperature $\left({ }^{\circ} \mathrm{C}\right)$ & $\begin{array}{c}\text { Concentration } \\
(\%, v / v)\end{array}$ & Time (min) & CONV & UAE \\
\hline $\mathrm{H}_{2} \mathrm{O}$ & 21.4 & - & 5 & $\mathrm{C} 1$ & $\mathrm{U} 25$ \\
\hline $\mathrm{H}_{2} \mathrm{O}$ & 21.4 & - & 15 & $\mathrm{C} 2$ & U26 \\
\hline $\mathrm{H}_{2} \mathrm{O}$ & 21.4 & - & 25 & $\mathrm{C} 3$ & U27 \\
\hline $\mathrm{H}_{2} \mathrm{O}$ & 21.4 & - & 35 & $\mathrm{C} 4$ & $\mathrm{U} 28$ \\
\hline $\mathrm{H}_{2} \mathrm{O}$ & 40 & - & 5 & $\mathrm{C} 5$ & U29 \\
\hline $\mathrm{H}_{2} \mathrm{O}$ & 40 & - & 15 & C6 & U30 \\
\hline $\mathrm{H}_{2} \mathrm{O}$ & 40 & - & 25 & $\mathrm{C} 7$ & U31 \\
\hline $\mathrm{H}_{2} \mathrm{O}$ & 40 & - & 35 & $\mathrm{C} 8$ & U32 \\
\hline $\mathrm{H}_{2} \mathrm{O}$ & 60 & - & 5 & C9 & U33 \\
\hline $\mathrm{H}_{2} \mathrm{O}$ & 60 & - & 15 & C10 & U34 \\
\hline $\mathrm{H}_{2} \mathrm{O}$ & 60 & - & 25 & C11 & U35 \\
\hline $\mathrm{H}_{2} \mathrm{O}$ & 60 & - & 35 & C12 & U36 \\
\hline $\mathrm{EtOH}$ & - & 20 & 5 & C13 & U37 \\
\hline $\mathrm{EtOH}$ & - & 20 & 15 & C14 & U38 \\
\hline $\mathrm{EtOH}$ & - & 20 & 25 & C15 & U39 \\
\hline $\mathrm{EtOH}$ & - & 20 & 35 & C16 & U40 \\
\hline $\mathrm{EtOH}$ & - & 50 & 5 & C17 & U41 \\
\hline $\mathrm{EtOH}$ & - & 50 & 15 & C18 & U42 \\
\hline $\mathrm{EtOH}$ & - & 50 & 25 & C19 & U43 \\
\hline $\mathrm{EtOH}$ & - & 50 & 35 & C20 & U44 \\
\hline $\mathrm{EtOH}$ & - & 80 & 5 & C21 & U45 \\
\hline $\mathrm{EtOH}$ & - & 80 & 15 & C22 & U46 \\
\hline $\mathrm{EtOH}$ & - & 80 & 25 & $\mathrm{C} 23$ & U47 \\
\hline $\mathrm{EtOH}$ & - & 80 & 35 & $\mathrm{C} 24$ & $\mathrm{U} 48$ \\
\hline
\end{tabular}

\subsection{Determination of Physicochemical Properties of Extracts}

The physicochemical properties of the aqueous and ethanolic chamomile extracts included the determination of (i) density $\left(\mathrm{g} \mathrm{cm}^{-1}\right)$, (ii) total soluble solids content (TSS, \%) only in water extracts, (iii) alcohol volume content (vol. \%) only in ethanol extracts by digital densitometer (Densito 30PX, Mettler-Toledo, Switzerland); (iv) pH value using a digital pH-meter (Sevenmulti, Mettler Toledo, Switzerland) and (v) total acid content (TA, \%), by potentiometric titration according to the AOAC [35].

\subsection{Determination of Antioxidant Bioactive Components}

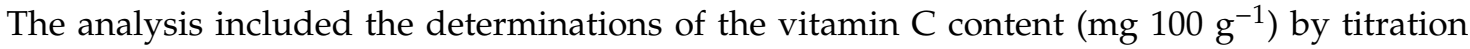
with 2,6-dichlorindophenol according to AOAC [36]; total phenol content (TPC) according to the Shukla et al. [37] as follows: $1 \mathrm{~mL}$ of the extract and $1 \mathrm{~mL}$ of the Folin-Ciocalteu reagent diluted with distilled water (1:2) were added in a volumetric flask with a volume of $50 \mathrm{~mL}$ and allowed to stand for $3 \mathrm{~min}$. Additionally, $3 \mathrm{~mL}$ of a saturated sodium carbonate solution was added, the flask was filled to the mark with distilled water and allowed to stand for $3 \mathrm{~h}$ at room temperature with intermittent shaking. The absorbance of the blue color was measured spectrophotometrically (Shimadzu UV 1650 PC, Shimadzu Co., Kioto, Japan) at $750 \mathrm{~nm}$ with distilled water as a blank; determination of total flavonoids content (TFC) according to the Abou-Arab and Abou-Salem [38] as follows: $1 \mathrm{~mL}$ of the extract, $1 \mathrm{~mL}$ of $20 \% \mathrm{HCl}(v / v)$ and $0.5 \mathrm{~mL}$ formaldehyde were added in a volumetric flask volume of $25 \mathrm{~mL}$. The prepared samples were blown with nitrogen $\left(\mathrm{N}_{2}\right)$ and allowed to stand for $24 \mathrm{~h}$ at room temperature. After $24 \mathrm{~h}$, the same Folin-Ciocalteu reaction as for the total phenols was carried out. As an external standard for TPC gallic acid, while for TFC catechin was used and the final content of TPC and TFC was expressed as mg GAE $100 \mathrm{~g}^{-1}$. Total non-flavonoid content (TNFC, mg GAE $100 \mathrm{~g}^{-1}$ ) was mathematically expressed as difference between TPC and TFC. 


\subsection{Determination of Antioxidant Capacity Using the ABTS Assay}

The antioxidant capacity of the chamomile extracts was determined by the ABTS method according to the Miller et al. [39] and Re et al. [40]. As an antioxidant standard Trolox was used, while for the preparation of stock solution $2.5 \mathrm{mM}$ Trolox was prepared in ethanol (80\%). For the preparation of the stable ABTS radical solution $\left(\mathrm{ABTS}^{\bullet+}\right), 5 \mathrm{~mL}$ of ABTS solution $(7 \mathrm{mM})$ and $88 \mu \mathrm{L}$ of potassium persulfate $(140 \mathrm{mM})$ solution were mixed and allowed to stand in the dark at room temperature for $16 \mathrm{~h}$. On the day of analysis, $1 \% \mathrm{ABTS}^{\bullet+}$ solution (in $96 \% \mathrm{EtOH}$ ) was prepared. A $160 \mu \mathrm{L}$ of extract was directly injected in the cuvette and mixed with $2 \mathrm{~mL} \mathrm{1 \%} \mathrm{ABTS}^{\bullet+}$. After $5 \mathrm{~min}$, the absorbance at $734 \mathrm{~nm}$ was measured (Shimadzu 1650 PC, Germany). The final results of the antioxidant capacity was calculated based on calibration curve and expressed as mmol TE L ${ }^{-1}$. ABTS, 2, 2' -azinobis (3-ethylbenzothiazoline-6-sulfonic acid), Trolox (6-hydroxy-2,5,7,8-tetramethylchroman-2-carboxylic acid) and potassium persulfate were supplied from Sigma-Aldrich (St. Louis, MO, USA).

\subsection{Statistical and Multivariate Analyses}

All treatments, as for the conventional and UAE extraction, were made in triplicate. Chemical analysis was performed in duplicate. Generalized linear model, including repetition, extraction method (conventional, UAE), solvent type $\left(\mathrm{H}_{2} \mathrm{O}, \mathrm{EtOH}\right)$ and time $(5,15,25$ and $35 \mathrm{~min})$ as categorical predictors, was used. For the analysis procedures PROC GLM in SAS software package, version 9.3. was used. The obtained data were analyzed using an analysis of the variance (ANOVA). Mean values were compared by the $t$-test (LSD) and were considered significantly different at $p \leq 0.0001$. In Tables different letters are shown to indicate significant differences between mean values within each column and also standard deviation $( \pm \mathrm{SD})$ was expressed.

Afterwards, the whole dataset (considering both cultivars) was exported into SIMCA 13 (Umetrics, Malmö, Sweden) and elaborated by means of supervised orthogonal projections to latent structures discriminant analysis (OPLS-DA). In particular, the variation between groups was separated into predictive and orthogonal components. The OPLS-DA score plots allowed us to observe similarities between the different treatments, then describing the parameters better depicting both differences and similarities. To validate the OPLS-DA model, the $\mathrm{R}^{2} \mathrm{Y}$ and $\mathrm{Q}^{2} \mathrm{Y}$ were inspected, together with Hotelling's T2 (using 95\% and 99\% confidence limits for suspect and strong outliers, respectively). Each OPLS-DA model built was cross-validated (CV-ANOVA; $p<0.01)$ and permutation testing $(n=100)$ was then carried out to exclude overfitting of the models. Finally, the most discriminant variables characterizing each model built were outlined by means of variables importance in projection (VIP) approach. The parameters possessing the highest discrimination potential were those possessing a VIP score $>1$.

\section{Conclusions}

Comparing the impact of treatment method (conventional vs. UAE) on investigated physicochemical properties, both of water and ethanol based extracts, could be concluded that the ultrasonic treatment had a positive effect on the total acid content, while other properties such as the density, total soluble solids and pH-value did not significantly change given the applied extraction method. The ultrasonic treatment exhibited a significant positive effect on the analyzed total phenol, flavonoid and non-flavonoid content. The highest total phenol content (718 mg GAE $\left.100 \mathrm{~g}^{-1}\right)$ was recorded in the ethanol based extract $(50 \%, v / v)$ treated by ultrasound for $35 \mathrm{~min}$. The ultrasonic treatment did not positively affect the vitamin $C$ content since a slight degradation of vitamin $C$ in extracts was recorded with ultrasonic application. Besides, multivariate statistics applied to the parameters under investigation allowed us to clearly discern between water and ethanol-based extracts, highlighting also a clear role of the cultivars under investigations in determining the observed differences. In addition, the most affected parameters as resulted by conventional vs UAE extraction methods were provided. In this regard, TSS, TA and volume content were found to possess the highest VIP scores, thus confirming 
their importance in discriminating Pitoma and Bode gold cultivars. Therefore, based on the obtained results, it is possible to conclude that prepared infusions and tinctures were a rich source of specialized metabolites, with the ultrasonic treatment as an effective tool for obtaining the increased yield of extracted compounds in a shorter time period, thereby simultaneously obtaining the final product with an increased nutritional value.

Author Contributions: Conceptualization, J.Š.Ž., I.Ž., S.R., M.B. and S.R.B.; methodology, J.Š.Ž., I.Ž., S.R., M.P., G.R. and L.L.; formal analysis, J.Š.Ž., I.Ž., S.R., M.P., A.G. and S.V.; writing-original draft preparation, J.Š.Ž., I.Ž., S.R, G.R., L.L., J.M.L.; writing-review and editing, F.J.B., J.M.L., and R.D.; project administration, M.B. All authors have read and agreed to the published version of the manuscript.

Funding: This research received no external funding.

Acknowledgments: Thanks to GAIN (Axencia Galega de Innovación) for supporting this research (grant number IN607A2019/01).

Conflicts of Interest: The authors declare no conflict of interest.

\section{References}

1. Gardiner, P. Complementary, holistic, and integrative medicine: Chamomile. Pediatr. Rev. 2007, $28,16-18$. [CrossRef] [PubMed]

2. Raal, A.; Orav, A.; Püssa, T.; Valner, C.; Malmiste, B.; Arak, E. Content of essential oil, terpenoids and polyphenols in commercial chamomile (Chamomilla recutita L. Rauschert) teas from different countries. Food Chem. 2012, 131, 632-638. [CrossRef]

3. Das, M. Chamomile: Medicinal, Biochemical and Agricultural Aspects; CRC Press: Boca Raton, FL, USA, 2014; ISBN 9780429102172.

4. Singh, O.; Khanam, Z.; Misra, N.; Srivastava, M.K. Chamomile (Matricaria chamomilla L.): An overview. Pharmacogn. Rev. 2011, 5, 82-95. [CrossRef] [PubMed]

5. Srivastava, J.K.; Gupta, S. Antiproliferative and apoptotic effects of chamomile extract in various human cancer cells. J. Agric. Food Chem. 2007, 55, 9470-9478. [CrossRef]

6. Srivastava, J.K.; Gupta, S. Extraction, characterization, stability and biological activity of flavonoids isolated from chamomile flowers. Mol. Cell Pharmacol. 2009, 1, 138. [CrossRef]

7. Sak, K.; Nguyen, T.H.; Ho, V.D.; Do, T.T.; Raal, A. Cytotoxic effect of chamomile (Matricaria recutita) and marigold (Calendula officinalis) extracts on human melanoma SK-MEL-2 and epidermoid carcinoma KB cells. Cogent Med. 2017, 4, 1333218. [CrossRef]

8. Putnik, P.; Bursać Kovačević, D.; Režek Jambrak, A.; Barba, F.J.; Cravotto, G.; Binello, A.; Lorenzo, J.M.; Shpigelman, A. Innovative "green" and novel strategies for the extraction of bioactive added value compounds from citruswastes-A review. Molecules 2017, 22, 680. [CrossRef]

9. Putnik, P.; Kresoja, Ž.; Bosiljkov, T.; Režek Jambrak, A.; Barba, F.J.; Lorenzo, J.M.; Roohinejad, S.; Granato, D.; Žuntar, I.; Bursać Kovačević, D. Comparing the effects of thermal and non-thermal technologies on pomegranate juice quality: A review. Food Chem. 2019, 279, 150-161. [CrossRef]

10. Jiang, T.; Zhan, S.; Li, S.; Zhu, Z.; He, J.; Lorenzo, J.M.; Barba, F.J. From 'green' technologies to 'red' antioxidant compounds extraction of purple corn: A combined ultrasound-ultrafiltration-purification approach. J. Sci. Food Agric. 2018, 98, 4919-4927. [CrossRef]

11. Roselló-Soto, E.; Barba, F.J.; Lorenzo, J.M.; Munekata, P.E.S.; Gómez, B.; Moltó, J.C. Phenolic profile of oils obtained from "horchata" by-products assisted by supercritical- $\mathrm{CO}_{2}$ and its relationship with antioxidant and lipid oxidation parameters: Triple TOF-LC-MS-MS characterization. Food Chem. 2019, 274, 865-871. [CrossRef]

12. Landeka Jurčević, I.; Dora, M.; Guberović, I.; Petras, M.; Rimac Brnčić, S.; Đikić, D. Polyphenols from wine lees as a novel functional bioactive compound in the protection against oxidative stress and hyperlipidaemia. Food Technol. Biotechnol. 2017, 55, 109-116.

13. Poojary, M.M.; Putnik, P.; Bursać Kovačević, D.; Barba, F.J.; Lorenzo, J.M.; Dias, D.A.; Shpigelman, A. Stability and extraction of bioactive sulfur compounds from Allium genus processed by traditional and innovative technologies. J. Food Compos. Anal. 2017, 61, 28-39. [CrossRef] 
14. Abdelkebir, R.; Alcántara, C.; Falcó, I.; Sánchez, G.; Garcia-Perez, J.V.; Neffati, M.; Lorenzo, J.M.; Barba, F.J.; Collado, M.C. Effect of ultrasound technology combined with binary mixtures of ethanol and water on antibacterial and antiviral activities of Erodium glaucophyllum extracts. Innov. Food Sci. Emerg. Technol. 2019, 52, 189-196. [CrossRef]

15. Roselló-Soto, E.; Martí-Quijal, F.; Cilla, A.; Munekata, P.; Lorenzo, J.; Remize, F.; Barba, F. Influence of temperature, solvent and $\mathrm{pH}$ on the selective extraction of phenolic compounds from tiger nuts by-products: Triple-TOF-LC-MS-MS characterization. Molecules 2019, 24, 797. [CrossRef]

16. Agregán, R.; Munekata, P.E.S.; Franco, D.; Dominguez, R.; Carballo, J.; Lorenzo, J.M. Phenolic compounds from three brown seaweed species using LC-DAD-ESI-MS/MS. Food Res. Int. 2017, 99, 979-985. [CrossRef]

17. Sahin, S.; Samli, R.; Birteks Z Tan, A.S.; Barba, F.J.; Chemat, F.; Cravotto, G.; Lorenzo, J.M. Solvent-free microwave-assisted extraction of polyphenols from olive tree leaves: Antioxidant and antimicrobial properties. Molecules 2017, 22, 1056. [CrossRef]

18. Bursać Kovačević, D.; Maras, M.; Barba, F.J.; Granato, D.; Roohinejad, S.; Mallikarjunan, K.; Montesano, D.; Lorenzo, J.M.; Putnik, P. Innovative technologies for the recovery of phytochemicals from Stevia rebaudiana Bertoni leaves: A review. Food Chem. 2018, 268, 513-521. [CrossRef]

19. Martínez-Patiño, J.C.; Gullón, B.; Romero, I.; Ruiz, E.; Brnčić, M.; Žlabur, J.Š.; Castro, E. Optimization of ultrasound-assisted extraction of biomass from olive trees using response surface methodology. Ultrason. Sonochem. 2019, 51, 487-495. [CrossRef]

20. Aadil, R.M.; Zeng, X.-A.; Han, Z.; Sun, D.-W. Effects of ultrasound treatments on quality of grapefruit juice. Food Chem. 2013, 141, 3201-3206. [CrossRef]

21. Zou, Y.; Hou, X. Sonication enhances quality and antioxidant activity of blueberry juice. Food Sci. Technol. 2017, 37, 599-603. [CrossRef]

22. Zou, Y.; Jiang, A. Effect of ultrasound treatment on quality and microbial load of carrot juice. Food Sci. Technol. 2016, 36, 111-115. [CrossRef]

23. Šic Žlabur, J.; Dobričević, N.; Pliestić, S.; Galić, A.; Bilić, D.; Voća, S. Antioxidant potential of fruit juice with added chokeberry powder (Aronia melanocarpa). Molecules 2017, 22, 2158. [CrossRef]

24. Beckett, M.A.; Hua, I. Impact of ultrasonic frequency on aqueous sonoluminescence and sonochemistry. J. Phys. Chem. A 2001, 105, 3796-3802. [CrossRef]

25. Knorr, D.; Zenker, M.; Heinz, V.; Lee, D.-U. Applications and potential of ultrasonics in food processing. Trends Food Sci. Technol. 2004, 15, 261-266. [CrossRef]

26. Dias, D.d.R.C.; Barros, Z.M.P.; Carvalho, C.B.O.d.; Honorato, F.A.; Guerra, N.B.; Azoubel, P.M. Effect of sonication on soursop juice quality. LWT Food Sci. Technol. 2015, 62, 883-889. [CrossRef]

27. Ordóñez-Santos, L.E.; Martínez-Girón, J.; Arias-Jaramillo, M.E. Effect of ultrasound treatment on visual color, vitamin C, total phenols, and carotenoids content in Cape gooseberry juice. Food Chem. 2017, 233, 96-100. [CrossRef]

28. Barba, F.J.; Putnik, P.; Bursać Kovačević, D.; Poojary, M.M.; Roohinejad, S.; Lorenzo, J.M.; Koubaa, M. Impact of conventional and non-conventional processing on prickly pear (Opuntia spp.) and their derived products: From preservation of beverages to valorization of by-products. Trends Food Sci. Technol. 2017, 67, 260-270. [CrossRef]

29. Šic Žlabur, J.; Voća, S.; Dobričević, N.; Brnčić, M.; Dujmić, F.; Rimac Brnčić, S. Optimization of ultrasound assisted extraction of functional ingredients from Stevia rebaudiana Bertoni leaves. Int. Agrophysics 2015, 29, 231-237. [CrossRef]

30. Ciğeroğlu, Z.; Aras, Ö.; Pinto, C.A.; Bayramoglu, M.; Kirbaşlar, S..I.; Lorenzo, J.M.; Barba, F.J.; Saraiva, J.A.; Şahin, S. Optimization of ultrasound-assisted extraction of phenolic compounds from grapefruit (Citrus paradisi Macf.) leaves via D-optimal design and artificial neural network design with categorical and quantitative variables. J. Sci. Food Agric. 2018, 98, 4584-4596. [CrossRef]

31. Putnik, P.; Lorenzo, J.; Barba, F.; Roohinejad, S.; Režek Jambrak, A.; Granato, D.; Montesano, D.; Bursać Kovačević, D. Novel food processing and extraction technologies of high-added value compounds from plant materials. Foods 2018, 7, 106. [CrossRef]

32. Roohi, R.; Abedi, E.; Hashemi, S.M.B.; Marszałek, K.; Lorenzo, J.M.; Barba, F.J. Ultrasound-assisted bleaching: Mathematical and 3D computational fluid dynamics simulation of ultrasound parameters on microbubble formation and cavitation structures. Innov. Food Sci. Emerg. Technol. 2019, 55, 66-79. [CrossRef] 
33. Šic Žlabur, J.; Colnar, D.; Voća, S.; Lorenzo, J.M.; Munekata, P.E.S.; Barba, F.J.; Dobričević, N.; Galić, A.; Dujmić, F.; Pliestić, S.; et al. Effect of ultrasound pre-treatment and drying method on specialized metabolites of honeyberry fruits (Lonicera caerulea var. kamtschatica). Ultrason. Sonochem. 2019, 56, 372-377. [CrossRef] [PubMed]

34. Ashokkumar, M.; Sunartio, D.; Kentish, S.; Mawson, R.; Simons, L.; Vilkhu, K.; Versteeg, C. (Kees) Modification of food ingredients by ultrasound to improve functionality: A preliminary study on a model system. Innov. Food Sci. Emerg. Technol. 2008, 9, 155-160. [CrossRef]

35. Cunniff, P. Official Methods of Analysis of AOAC International, 16th ed.; The AOAC Association: Washington, DC, USA, 1995; ISBN 9780935584547.

36. AOAC International. Official Methods of Analysis of AOAC International. Volume 1, Agricultural Chemicals; Contaminants; Drugs; AOAC International: Washington, DC, USA, 2000; ISBN 0935584676.

37. Shukla, S.; Mehta, A.; Mehta, P.; Bajpai, V.K. Antioxidant ability and total phenolic content of aqueous leaf extract of Stevia rebaudiana Bert. Exp. Toxicol. Pathol. 2012, 64, 807-811. [CrossRef]

38. Abou-Arab, E.A.; Abu-Salem, F.M. Evaluation of bioactive compounds of Stevia rebaudiana leaves and callus. African J. Food Sci. 2010, 4, 627-634.

39. Miller, N.J.; Rice-Evans, C.; Davies, M.J.; Gopinathan, V.; Milner, A. A Novel Method for Measuring Antioxidant Capacity and Its Application to Monitoring the Antioxidant Status in Premature Neonates. Clin. Sci. 1993, 84, 407-412. [CrossRef]

40. Re, R.; Pellegrini, N.; Proteggente, A.; Pannala, A.; Yang, M.; Rice-Evans, C. Antioxidant activity applying an improved ABTS radical cation decolorization assay. Free Radic. Biol. Med. 1999, 26, 1231-1237. [CrossRef]

(C) 2020 by the authors. Licensee MDPI, Basel, Switzerland. This article is an open access article distributed under the terms and conditions of the Creative Commons Attribution (CC BY) license (http://creativecommons.org/licenses/by/4.0/). 